\title{
Dietary Pattern As a Risk Factor of Diabetes Mellitus and Obesity: Meta-Analysis
}

\author{
Linda Wahyu Septianawati'), Yulia Lanti Retno Dewi²), \\ Eti Poncorini Pamungkasari²) \\ 1)Masters Program in Public Health, Universitas Sebelas Maret \\ 2)Faculty of Medicine, Universitas Sebelas Maret
}

\section{ABSTRACT}

Background: Non-Communicable Disease is a disease that is considered unable to transmit or spread from one person to another but is a cause of death globally, especially diabetes mellitus and obesity. According to $\mathrm{WHO}$, the number of deaths due to PTM in 2016 was 40.5 million (71\%) worldwide. Diet is one of the risk factors for Diabetes Mellitus and Obesity. This study aims to analyze the effect of diet as a risk factor for diabetes mellitus and obesity.

Subjects and Method: This study was a systematic review and meta-analysis using a cross-sectional design. The articles used in this study were obtained from several databases, including PubMed, Google Scholar, Springerlink, and ScienceDirect. The articles used in this study were those published from 20112020. The article search was carried out by considering the eligibility criteria defined using the PICO model. P: adults, I: unhealthy eating patterns, C: healthy eating patterns, and O: Diabetes Mellitus and Obesity. The keywords to search for articles were "dietary pattern", "risk", "obesity", and "diabetes mellitus," and "adjusted odds ratio". The articles included in this study were full-text articles with cross-sectional study design. Articles were collected using PRISMA flow diagrams. Articles were analyzed using the Review Manager 5.3 application.

Results: A total of 15 articles were reviewed in this study. The meta-analysis showed that an unhealthy diet increased the risk of Diabetes $(\mathrm{aOR}=1.65 ; 95 \% \mathrm{CI}=1.29$ to $2.11 ; \mathrm{p}<0.001)$. The meta-analysis of 9 articles also showed that an unhealthy diet increased the risk of obesity $(\mathrm{aOR}=1.42 ; 95 \% \mathrm{CI}=1.21$ to $2.66 ; \mathrm{p}<0.001)$. This meta-analysis combines primary studies from Swaziland, China, Ethiopia, Kenya, America, Malaysia, Ghana, Romania, Nepal, Ireland, and Korea.

Conclusion: Unhealthy diet is a risk factor for diabetes mellitus and obesity.

Keywords:dietary pattern, diabetes mellitus, obesity, cross-sectional

\section{Correspondence:}

Linda Wahyu Septiananwati. Masters Program in Public Health, Universitas Sebelas Maret, Jl. Ir. Sutami 36A, Surakarta 57126, Central Java. Email: lindatian81@gmail.com.

\section{Cite this as:}

Septianawati LW, Dewi YLR, Pamungkasari EP (2021). Dietary Pattern As a Risk Factor of Diabetes Mellitus and Obesity: Meta-Analysis. Indones J Med. 06(01): 82-94. https://doi.org/10.26911/theijmed.2021.06.01.09.

\section{BACKGROUND}

Non-Communicable Disease (NCD) is a disease that is considered unable to be transmitted or spread from one person to another but is a global cause of death (Irwan, 2018). According to WHO, the number of deaths due to PTM in 2016 was
40.5 million (71\%) worldwide. Due to PTM in the world in detail, the mortality rate consists of $4 \%$ at the age of fewer than 30 years, $38 \%$ at the age between 30 to 70 years, $58 \%$ at the age more than 70 years. In Indonesia, the death rate caused by NCD in 2016 was 1.3 million (73\%) of all cases of 
death (WHO, 2018). NCD consists of various diseases, namely cardiovascular disease (coronary heart disease, stroke), cancer, chronic respiratory disease(asthma, chronic obstructive pulmonary disease), and diabetes (WHO, 2018)

According to the World Health Organization (WHO) estimates, globally, 422 million adults over 18 years of age lived with diabetes in 2014. The latest data from the International Diabetes Federation (IDF) Atlas in 2018 shows that Indonesia is ranked 6th globally with 10.3 million people with diabetes mellitus.

Another non-communicable disease that is no less dangerous after diabetes is obesity. The prevalence of obesity in the world almost tripled between 1975 and 2016. Based on data from the World Health Organization (WHO) in 2018, in 2016, there were 1.9 billion adults aged 18 years. And above who are overweight and more than 650 million cases of obesity.

Non-communicable disease arises from a combination of non-modifiable risk factors and modifiable risk factors. The risk factors that cannot be modified by an individual are age, sex, and genetics. Meanwhile, modifiable risk factors can be changed through individual awareness and social intervention, especially regarding diet (Nabilah, 2016). Dietary pattern is a variety of information that provides an overview of the kinds and amounts of food ingredients eaten every day by one person and is a characteristic for a particular community group (Kadir, 2016). This dietary pattern is influenced by several things, including habits, enjoyment, culture, religion, economic level, natural environment, etc. (Sing, 2012).

It is believed that the principles of the Nutrition Guide for Balanced Diet, agreed upon by the 1992 world food conference in Rome, will be able to overcome the double burden of nutritional problems, both deficiency and excess nutrition. In Indonesia, this principle is known as the guidelines for balanced nutrition. Guidelines for balanced nutrition, namely: daily food consumption must contain nutrients in the type and amount (portion) according to each person's needs or age group.

\section{SUBJECTS AND METHOD}

\section{Study Design}

This study was a systematic review and meta-analysis. The articles used in this study were obtained from several databases, including PubMed, Google Scholar, Springerlink, and ScienceDirect. The keywords used to search for articles were: "dietary pattern", "risk" "obesity", and "diabetes mellitus," and "adjusted odds ratio".

\section{Inclusion Criteria}

The articles included in this study were full paper articles with a cross-sectional study design and in English. Appropriate articles should mention the adult population, unhealthy diet interventions with diabetes mellitus, and obesity outcomes. Articles should be published in 2011-2020 with a multivariate-adjusted Odds Ratio.

\section{Exclusion Criteria}

The articles issued in this study were articles that use the subject of toddlers and pregnant women. Articles with results were not adjusted to Odds Ratio.

\section{Operational Definition of Variables}

The article search was carried out by considering the eligibility criteria defined using the PICO model. The study population were adults with an intervention in the form of an unhealthy diet, comparison, namely a healthy diet and outcomes in the form of Diabetes Mellitus and obesity.

Dietary pattern was a method or effort in regulating the amount and type of food with specific purposes such as maintaining 
health, nutritional status, preventing or helping to cure diseases.

Diabetes Mellitus was a collection of symptoms that arise in a person caused by an increase in blood sugar (glucose) levels due to an absolute or relative lack of insulin.

Obesity was an excessive accumulation of fat due to an imbalance of energy intake and energy used (energy expenditure) for a long time.

\section{Data Analysis}

Data processing was carried out by the Review Manager (RevMan 5.3) by calculating the effect size and heterogeneity to deter- mine which research models were combined and formed the final meta-analysis result.

\section{RESULTS}

The process of searching for articles by searching through a database with journals can be seen in Figure 1. Figure 2 shows the areas where articles were drawn according to the inclusion criteria. 5 articles were obtained from the continent of Africa, 6 articles from the continent of Asia, 2 articles from the continent of Africa, and 2 articles from North America.

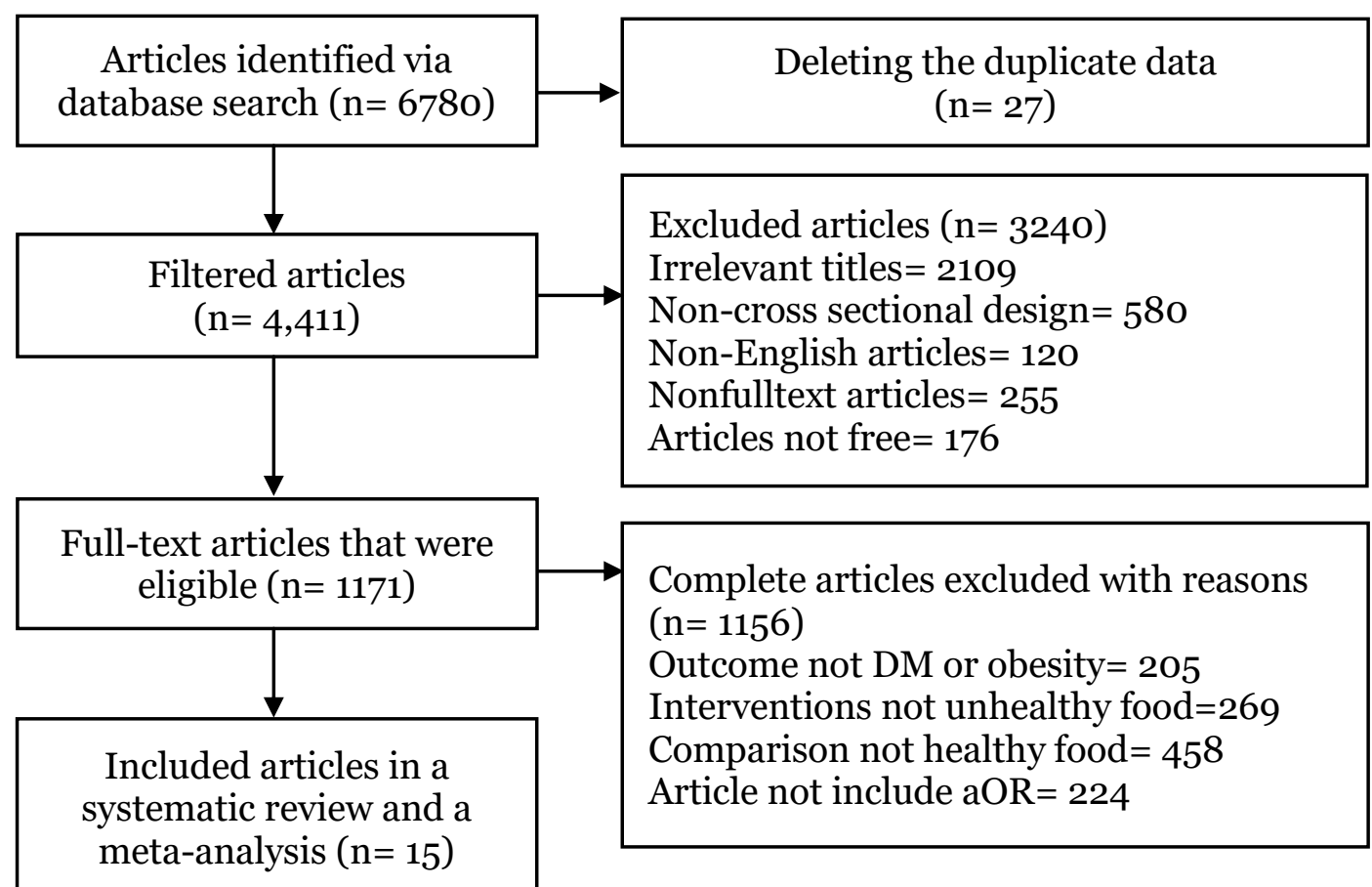

Figure 1. PRISMA flow diagram 
1. Dietary Pattern during Pregnancy as a Risk Factor for Diabetes Mellitus

a. Summary of Source Articles

Table 1. Descriptions of primary studies included in the meta-analysis

\begin{tabular}{|c|c|c|c|c|c|c|c|c|}
\hline $\begin{array}{c}\text { Author } \\
\text { (year) }\end{array}$ & Title & Country & $\begin{array}{c}\text { Study } \\
\text { Design }\end{array}$ & Sample & $\begin{array}{c}\mathbf{P} \\
\text { Population } \\
\end{array}$ & $\begin{array}{c}\text { I } \\
\text { Intervention }\end{array}$ & $\begin{array}{c}\mathrm{C} \\
\text { Comparison }\end{array}$ & $\begin{array}{c}\text { O } \\
\text { Outcome }\end{array}$ \\
\hline $\begin{array}{l}\text { Gbadamosi } \\
\text { and Tlou } \\
(2020)\end{array}$ & $\begin{array}{l}\text { Modifiable risk factors associated } \\
\text { with non-communicable diseases } \\
\text { among adult outpatients in } \\
\text { Manzini, Swaziland: a cross- } \\
\text { sectional study }\end{array}$ & $\begin{array}{l}\text { Manzini, } \\
\text { Swaziland }\end{array}$ & Crossectional & 385 & $\begin{array}{l}\text { Subjects } \\
\text { aged } 18 \text { years } \\
\text { and over }\end{array}$ & $\begin{array}{l}\text { Unhealthy eating } \\
\text { and drinking } \\
\text { (high in sugar) }\end{array}$ & Healthy food & $\begin{array}{l}\text { Diabetes } \\
\text { Mellitus }\end{array}$ \\
\hline $\begin{array}{l}\text { Shu et al. } \\
(2017)\end{array}$ & $\begin{array}{l}\text { Dietary patterns are associated with } \\
\text { type } 2 \text { diabetes mellitus among } \\
\text { middle-aged adults in Zhejiang } \\
\text { Province, China }\end{array}$ & $\begin{array}{l}\text { Zhejiang } \\
\text { Province, } \\
\text { China }\end{array}$ & Crossectional & 1918 & $\begin{array}{l}\text { Subjects } \\
\text { aged } 45-59 \\
\text { years }\end{array}$ & $\begin{array}{l}\text { Eating and } \\
\text { drinking (high fat, } \\
\text { high sugar, } \\
\text { western food) }\end{array}$ & Healthy food & $\begin{array}{l}\text { Diabetes } \\
\text { Mellitus }\end{array}$ \\
\hline $\begin{array}{l}\text { Abas } \\
(2019)\end{array}$ & $\begin{array}{l}\text { Prevalence and associated risk } \\
\text { factors for type } 2 \text { diabetes mellitus } \\
\text { among adults ( }>=40 \text { years of age) } \\
\text { in jigjiga City, Somali region, } \\
\text { Eastern Ethiopia }\end{array}$ & $\begin{array}{l}\text { Somali, } \\
\text { Ethiopia }\end{array}$ & Crossectional & 175 & $\begin{array}{l}\text { Subjects } \\
\text { aged } 40 \\
\text { years and } \\
\text { over }\end{array}$ & $\begin{array}{l}\text { Eat and drink } \\
\text { (high fat, high } \\
\text { sugar) }\end{array}$ & Healthy food & $\begin{array}{l}\text { Diabetes } \\
\text { Mellitus }\end{array}$ \\
\hline $\begin{array}{l}\text { Okube et al. } \\
(2020)\end{array}$ & $\begin{array}{l}\text { Association of dietary patterns and } \\
\text { practices on metabolic syndrome in } \\
\text { adults with central obesity attend- } \\
\text { ing a mission hospital in Kenya: a } \\
\text { cross-sectional study }\end{array}$ & Kenya & Crossectional & 404 & $\begin{array}{l}\text { Subjects } \\
\text { aged 18-64 } \\
\text { years }\end{array}$ & $\begin{array}{l}\text { Eat and drink } \\
\text { (high fat, high } \\
\text { sugar) }\end{array}$ & Healthy food & $\begin{array}{l}\text { Diabetes } \\
\text { Mellitus }\end{array}$ \\
\hline $\begin{array}{l}\text { Lee et al. } \\
(2018)\end{array}$ & $\begin{array}{l}\text { Food insecurity is associated with } \\
\text { prediabetes and dietary differences } \\
\text { in U.S. adults aged } 20-39\end{array}$ & $\begin{array}{l}\text { United } \\
\text { States }\end{array}$ & Crossectional & 3684 & $\begin{array}{l}\text { Subjects } \\
\text { aged 20-39 } \\
\text { years }\end{array}$ & $\begin{array}{l}\text { Eat and drink } \\
\text { (high fat, high } \\
\text { sugar) }\end{array}$ & Healthy food & $\begin{array}{l}\text { Diabetes } \\
\text { Mellitus }\end{array}$ \\
\hline $\begin{array}{l}\text { Chopra and } \\
\text { Chopra } \\
(2016)\end{array}$ & $\begin{array}{l}\text { Risk perception for diabetes in } \\
\text { Appalachian women }\end{array}$ & $\begin{array}{l}\text { Appalachia, } \\
\text { New York, } \\
\text { Amerika }\end{array}$ & Crossectional & 202 & $\begin{array}{l}\text { Subjects } \\
\text { aged } 21-50 \\
\text { years }\end{array}$ & $\begin{array}{l}\text { Food habits high } \\
\text { in sugar, high } \\
\text { sugar, fizzy }\end{array}$ & Healthy food & $\begin{array}{l}\text { Diabetes } \\
\text { Mellitus }\end{array}$ \\
\hline $\begin{array}{l}\text { Karupaiah } \\
\text { et al. (2019) }\end{array}$ & $\begin{array}{l}\text { A cross-sectional study on the } \\
\text { Dietary pattern impact on cardio- } \\
\text { vascular Disease Biomarkers in } \\
\text { Malaysia }\end{array}$ & Malaysia & Crossectional & 577 & $\begin{array}{l}\text { The subject } \\
\text { of adults in } \\
\text { Malaysia }\end{array}$ & $\begin{array}{l}\text { High-fat, high- } \\
\text { sugar, fizzy food } \\
\text { habits }\end{array}$ & Healthy food & $\begin{array}{l}\text { Diabetes } \\
\text { Mellitus }\end{array}$ \\
\hline $\begin{array}{l}\text { Lee et al. } \\
(2017)\end{array}$ & $\begin{array}{l}\text { A Healthy Beverage Consumption } \\
\text { Pattern Is Inversely Associated with } \\
\text { the Risk of Obesity and Metabolic }\end{array}$ & Korea & Crossectional & 19.800 & $\begin{array}{l}\text { Subjects } \\
\text { aged } 20 \text { and } \\
\text { over }\end{array}$ & $\begin{array}{l}\text { Foods high in fat } \\
\text { and high in sugar }\end{array}$ & Healthy food & $\begin{array}{l}\text { Diabetes } \\
\text { Mellitus }\end{array}$ \\
\hline
\end{tabular}




\begin{tabular}{|c|c|c|c|c|c|c|c|c|}
\hline & Abnormalities in Korean Adults & & & & & & & \\
\hline $\begin{array}{l}\text { Yin et al. } \\
\text { 2020) }\end{array}$ & $\begin{array}{l}\text { Association of dietary patterns with } \\
\text { the newly diagnosed diabetes } \\
\text { mellitus and central obesity: a } \\
\text { community-based cross-sectional } \\
\text { study }\end{array}$ & China & Crossectional & 1432 & $\begin{array}{l}\text { Subjects } \\
\text { aged } 40-65 \\
\text { years }\end{array}$ & $\begin{array}{l}\text { Foods high in fat } \\
\text { and high in sugar }\end{array}$ & Healthy food & $\begin{array}{l}\text { Diabetes } \\
\text { Mellitus }\end{array}$ \\
\hline
\end{tabular}

\section{Dietary Pattern as a Risk Factor for Obesity}

a. Summary of Source Articles

Table 2. Descriptions of primary studies included in the meta-analysis

\begin{tabular}{|c|c|c|c|c|c|c|c|c|}
\hline $\begin{array}{c}\text { Author } \\
\text { (year) }\end{array}$ & Title & Country & $\begin{array}{c}\text { Study } \\
\text { Design }\end{array}$ & Sample & $\begin{array}{c}\mathbf{P} \\
\text { Population } \\
\end{array}$ & $\begin{array}{c}\text { I } \\
\text { Intervention } \\
\end{array}$ & $\begin{array}{c}\mathrm{C} \\
\text { Comparison } \\
\end{array}$ & $\begin{array}{c}\text { O } \\
\text { Outcome }\end{array}$ \\
\hline $\begin{array}{l}\text { Mogre et al. } \\
(2015)\end{array}$ & $\begin{array}{l}\text { Demographic, dietary and physical } \\
\text { activity predictors of general and abdo- } \\
\text { minal obesity among university } \\
\text { students }\end{array}$ & Ghana & Crossectional & 552 & $\begin{array}{l}\text { College } \\
\text { student }\end{array}$ & $\begin{array}{l}\text { Foods high in } \\
\text { fat and } \\
\text { carbohydrates }\end{array}$ & Healthy food & Obesity \\
\hline $\begin{array}{l}\text { Zou et al. } \\
(2017)\end{array}$ & $\begin{array}{l}\text { Dietary Patterns and Obesity among } \\
\text { Chinese Adults }\end{array}$ & $\begin{array}{l}\text { Zhejiang, } \\
\text { cina }\end{array}$ & Crossectional & 1613 & Adult subject & $\begin{array}{l}\text { Foods high in } \\
\text { fat and } \\
\text { carbohydrates }\end{array}$ & Healthy food & Obesity \\
\hline $\begin{array}{l}\text { Roman et al. } \\
(2019)\end{array}$ & $\begin{array}{l}\text { Dietary patterns and their association } \\
\text { with obesity: a cross-sectional study }\end{array}$ & Romania & Crossectional & 1398 & Adult subject & $\begin{array}{l}\text { Foods high in } \\
\text { fat }\end{array}$ & Healthy food & Obesity \\
\hline $\begin{array}{l}\text { Okube et al. } \\
(2020)\end{array}$ & $\begin{array}{l}\text { Association of dietary patterns and } \\
\text { practices on metabolic syndrome in } \\
\text { adults with central obesity attending a } \\
\text { mission hospital }\end{array}$ & Kenya & Crossectional & 404 & $\begin{array}{l}\text { Subjects } \\
\text { aged } 18-64 \\
\text { years }\end{array}$ & $\begin{array}{l}\text { Foods high in } \\
\text { fat and } \\
\text { carbohydrates }\end{array}$ & Healthy food & Obesity \\
\hline $\begin{array}{l}\text { Shrestha et } \\
\text { al. (2015) }\end{array}$ & $\begin{array}{l}\text { Food patterns measured by principal } \\
\text { component analysis and obesity in the } \\
\text { Nepalese adult }\end{array}$ & Nepal & Crossectional & 1073 & $\begin{array}{l}\text { Subjects } \\
\text { aged } 18 \text { and } \\
\text { over }\end{array}$ & $\begin{array}{l}\text { Foods high in } \\
\text { fat }\end{array}$ & Healthy food & Obesity \\
\hline $\begin{array}{l}\text { O'Brien et al. } \\
(2020)\end{array}$ & $\begin{array}{l}\text { Overweight and obesity in shift } \\
\text { workers: associated dietary and } \\
\text { lifestyle factors }\end{array}$ & Irlandia & Crossectional & 1080 & $\begin{array}{l}\text { Subjects } \\
\text { aged } 18 \text { and } \\
\text { over }\end{array}$ & $\begin{array}{l}\text { Foods high in } \\
\text { fat and } \\
\text { cholesterol }\end{array}$ & Healthy food & Obesity \\
\hline $\begin{array}{l}\text { Lee et al. } \\
(2018)\end{array}$ & $\begin{array}{l}\text { A Healthy Beverage Consumption } \\
\text { Pattern Is Inversely Associated with } \\
\text { the Risk of Obesity and Metabolic } \\
\text { Abnormalities in Korean Adults }\end{array}$ & Korea & Crossectional & 19.800 & $\begin{array}{l}\text { Subjects } \\
\text { aged } 20 \text { and } \\
\text { over }\end{array}$ & $\begin{array}{l}\text { Foods high in } \\
\text { fat and high in } \\
\text { sugar }\end{array}$ & Healthy food & Obesity \\
\hline
\end{tabular}


Septianawati et al./ Dietary Pattern As a Risk Factor of Diabetes Mellitus and Obesity

\begin{tabular}{|c|c|c|c|c|c|c|c|c|}
\hline $\begin{array}{l}\text { Yin et al. } \\
(2020)\end{array}$ & $\begin{array}{l}\text { Association of dietary patterns with the } \\
\text { newly diagnosed diabetes mellitus and } \\
\text { central obesity }\end{array}$ & China & Crossectional & 1432 & $\begin{array}{l}\text { Subjects } \\
\text { aged } 40-65 \\
\text { years }\end{array}$ & $\begin{array}{l}\text { Foods high in } \\
\text { fat and high in } \\
\text { sugar }\end{array}$ & Healthy food & Obesity \\
\hline $\begin{array}{l}\text { Dagne et al. } \\
\text { (2019) }\end{array}$ & $\begin{array}{l}\text { Factors associated with overweight and } \\
\text { obesity among adults in northeast } \\
\text { Ethiopia: a cross-sectional study }\end{array}$ & Etiopia & Crossectional & 751 & $\begin{array}{l}\text { Subjects } \\
\text { aged } 18-64 \\
\text { years }\end{array}$ & $\begin{array}{l}\text { Foods high in } \\
\text { fat and high in } \\
\text { sugar }\end{array}$ & Healthy food & Obesity \\
\hline
\end{tabular}


Septianawati et al./ Dietary Pattern As a Risk Factor of Diabetes Mellitus and Obesity

\section{b. Forest Plot}

\begin{tabular}{|c|c|c|c|c|c|c|c|c|}
\hline Study or Subgroup & $\log [$ Odds Ratio] & & Weight & $\begin{array}{l}\text { Odds Ratio } \\
\text { |V, Random, } 95 \% \mathrm{Cl}\end{array}$ & & $\begin{array}{r}\text { Odds } \\
\text { IV, Rande }\end{array}$ & $\begin{array}{l}\text { s Ratio } \\
\text { om, } 95 \% \mathrm{Cl}\end{array}$ & \\
\hline \multicolumn{9}{|l|}{ 1.1.1 crossec } \\
\hline Abdulahi Haji 2019 & 1.2556 & 0.4581 & $5.6 \%$ & $3.51[1.43,8.61]$ & & & - & \\
\hline Arthur M 2018 & 0.3075 & 0.1569 & $16.2 \%$ & $1.36[1.00,1.85]$ & & & - & \\
\hline Ishveen Chopra 2016 & 0.1484 & 0.1019 & $19.0 \%$ & $1.16[0.95,1.42]$ & & & 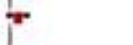 & \\
\hline Kyung Won Lee 2018 & 0.131 & 0.0618 & $20.7 \%$ & $1.14[1.01,1.29]$ & & & $=$ & \\
\hline Long Shu 2017 & 0.7747 & 0.2015 & $14.0 \%$ & $2.17[1.46,3.22]$ & & & - & \\
\hline Mojeed 2020 & 0.6861 & 0.433 & $6.1 \%$ & $1.99[0.85,4.64]$ & & & & \\
\hline Okubatsion Tekeste Okube 2020 & 0.4088 & 0.6439 & $3.2 \%$ & $1.51[0.43,5.32]$ & & & & \\
\hline tilakavati karupaiah & 1.1969 & 0.3583 & $7.9 \%$ & $3.31[1.64,6.68]$ & & & - & \\
\hline $\begin{array}{l}\text { Xueyao Yin } 2020 \\
\text { Subtotal (95\% Cl) }\end{array}$ & 0.9478 & 0.378 & $\begin{array}{r}7.3 \% \\
100.0 \%\end{array}$ & $\begin{array}{l}2.58[1.23,5.41] \\
1.65[1.29,2.11]\end{array}$ & & & $\vec{s}$ & \\
\hline \multicolumn{9}{|c|}{$\begin{array}{l}\text { Helerogeneily: } T a u^{2}=0.07 ; C h \mathrm{P}^{2}=27.82, \mathrm{df}=8(P=0.0005) ; 1^{2}=71 \% \\
\text { Test tor overall effect: } Z=3.99(P<0.0001)\end{array}$} \\
\hline Total $(95 \% \mathrm{Cl})$ & & & $100.0 \%$ & $1.65[1.29,2.11]$ & & & $\checkmark$ & \\
\hline $\begin{array}{l}\text { Heterogeneily: } \operatorname{Ta}^{2}=0.07 ; \mathrm{Ch}^{2}= \\
\text { Test for overall effect: } \mathrm{Z}=3.99 \text { (P. } \\
\text { Test for subarouo differences: Not }\end{array}$ & $\begin{array}{l}7.82, \mathrm{df}=8(\mathrm{P}=0 . \\
0.0001) \\
\text { oplicable }\end{array}$ & $0.0005 ;$ & $z^{2}=71 \%$ & & 0.01 & 0.1 Healthy & $\begin{aligned} 1 \\
\text { Unhealth }\end{aligned}$ & 100 \\
\hline
\end{tabular}

Figure 3. Forest Plot of Diet as a Risk Factor for Diabetes

Based on the forest plot results (Figure 3), an unhealthy diet could increase the risk of diabetes mellitus by 1.65 times compared to a healthy diet with statistical significance

\section{c. Funnel Plot}

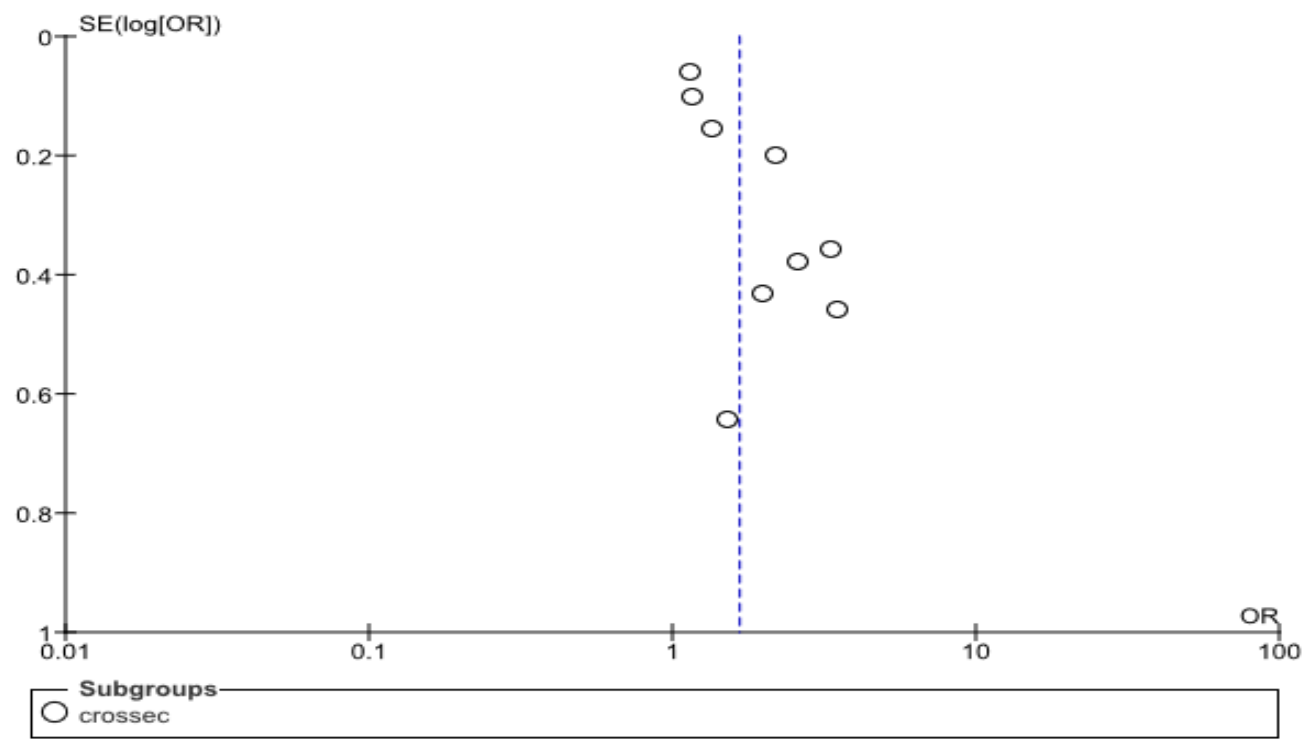

Figure 4. Funnel Plot of Diet as a Risk Factor for Diabetes Mellitus

The funnel plot (figure 4) shows a publication bias, characterized by an asymmetry of the right and left plots where 5 plots are on the right, and 1 plot was on the $(p=0.001)$. The heterogeneity of the research data showed $\mathrm{I}^{2}=71 \%$. The distribution of the data was stated as heterogeneous (random effect model). left. The plot on the graph's right had a standard error (SE) between 0.2 and o.6. The plot on the left of the graph had a standard error (SE) of 0.6. 
Septianawati et al./ Dietary Pattern As a Risk Factor of Diabetes Mellitus and Obesity

\section{b. Forest Plot}

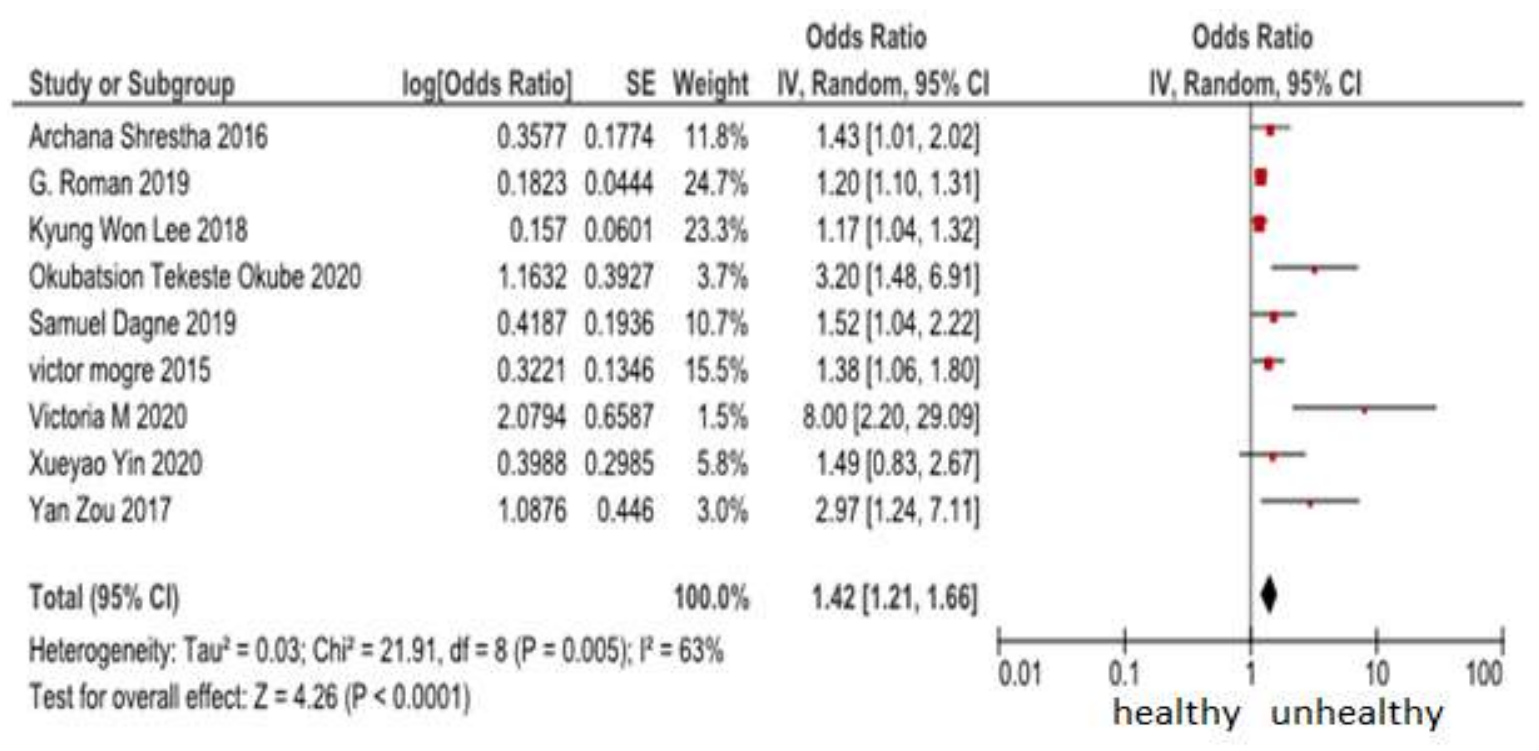

Figure 5. Forest Plot of Diet asRisk Factors for Obesity Disease

Meta-analysis can be seen through the forest plot (Figure 5) showing that an unhealthy diet can increase the risk of obesity by 1.42 times compared to consuming healthy foods and statistically significant( $\mathrm{p}<0.0001)$. The heterogeneity of the research data shows $\mathrm{I} 2=63 \%$, so that the distribution of the data is heterogeneous (random effect model).

\section{c. Funnel Plot}

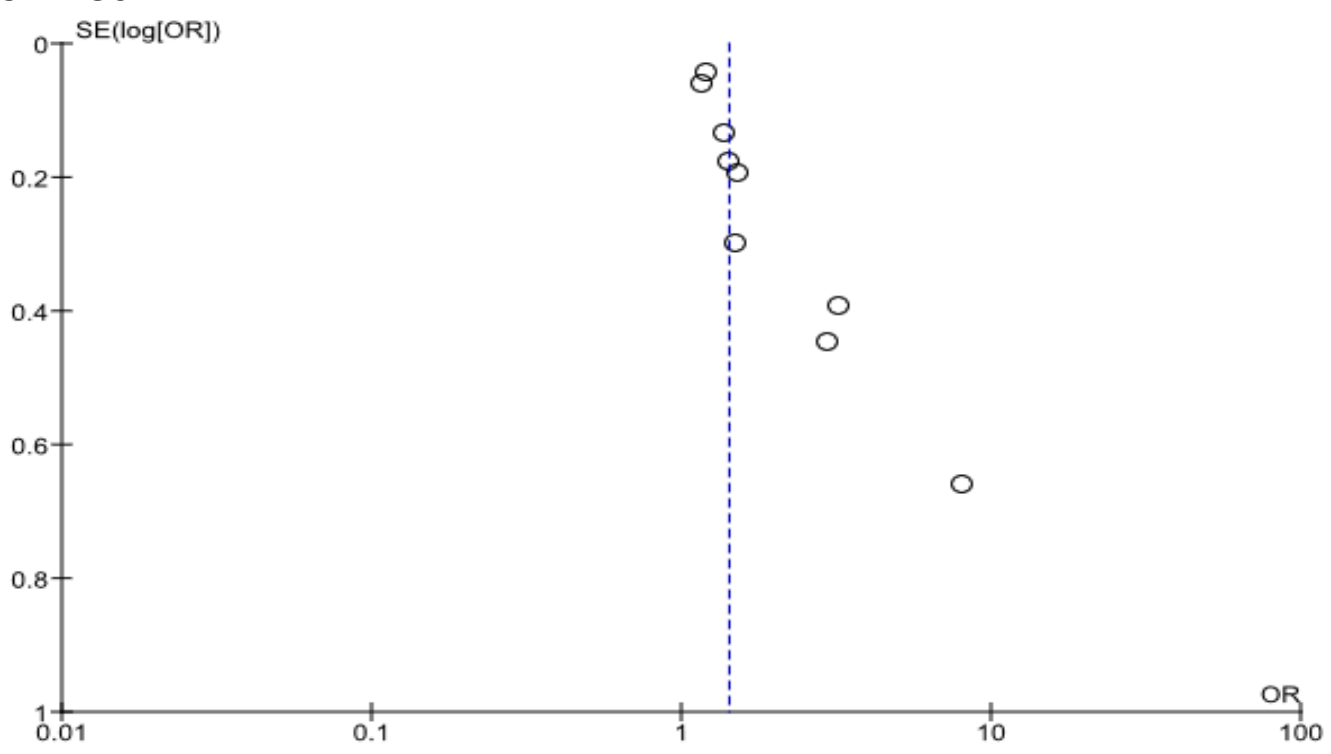

Figure 6. Funnel Plot of Diet As Risk Factors for Obesity

Figure 6 shows that there is a publication bias based on the funnel plot, which is characterized by an asymmetry of the right and left plots where 5 plots were on the right, 3 plots were on the left, and 1 plot was in the middle. The plot on the graph's right had a standard error (SE) between 0.2 and 0.7. The plot on the left of the graph had a standard error (SE) between 0 and 0.2 . 
Tabel 3. Critical Appraisal Checklist for Cross-sectional Study

\begin{tabular}{|c|c|c|c|c|c|c|c|c|c|}
\hline Checklist questions & $\begin{array}{l}\text { Gbadamosi } \\
\text { et al. } \\
(\mathbf{2 0 2 0}) \\
\end{array}$ & $\begin{array}{l}\text { Shu et } \\
\text { al. } \\
(2017)\end{array}$ & $\begin{array}{l}\text { Abas } \\
\text { et al. } \\
(2019) \\
\end{array}$ & $\begin{array}{c}\text { Okube } \\
\text { et al. } \\
(2020) \\
\end{array}$ & $\begin{array}{l}\text { Lee et } \\
\text { al. } \\
(2018)\end{array}$ & $\begin{array}{c}\text { Chopra } \\
\text { et al. } \\
\text { (2016) } \\
\end{array}$ & $\begin{array}{l}\text { Karupaiah } \\
\text { et al. } \\
\text { (2019) } \\
\end{array}$ & $\begin{array}{l}\text { Lee et al. } \\
(2017)\end{array}$ & $\begin{array}{l}\text { Yin et al. } \\
(2020)\end{array}$ \\
\hline $\begin{array}{l}\text { Does this objective address the } \\
\text { focus/research problem? }\end{array}$ & 1 & 1 & 1 & 1 & 1 & 1 & 1 & 1 & 1 \\
\hline $\begin{array}{l}\text { Is the research method (research } \\
\text { design) appropriate for answering } \\
\text { research questions? }\end{array}$ & 1 & 1 & 1 & 1 & 1 & 1 & 1 & 1 & 1 \\
\hline $\begin{array}{l}\text { Is the method of selecting } \\
\text { research subjects written? }\end{array}$ & 1 & 1 & 1 & 1 & 1 & 1 & 1 & 1 & 1 \\
\hline $\begin{array}{l}\text { Can the sampling method raise } \\
\text { bias (selection)? }\end{array}$ & $\mathrm{O}$ & o & o & $\mathrm{O}$ & $\mathrm{O}$ & 1 & $\mathrm{o}$ & o & o \\
\hline $\begin{array}{l}\text { Does the research sample taken } \\
\text { represent the designated } \\
\text { population? }\end{array}$ & 1 & 1 & 1 & 1 & 1 & 1 & 1 & 1 & 1 \\
\hline $\begin{array}{l}\text { Is the sample size based on pre- } \\
\text { study considerations? }\end{array}$ & o & o & 1 & o & o & o & o & o & $\mathrm{O}$ \\
\hline $\begin{array}{l}\text { Is a satisfactory response } \\
\text { achieved? }\end{array}$ & 1 & 1 & 1 & 1 & 1 & 1 & 1 & 1 & 1 \\
\hline $\begin{array}{l}\text { Are the research instruments } \\
\text { valid and reliable? }\end{array}$ & 1 & 1 & 1 & 1 & 1 & 1 & 1 & 1 & 1 \\
\hline $\begin{array}{l}\text { Is statistical significance } \\
\text { assessed? }\end{array}$ & 1 & 1 & 1 & 1 & 1 & 1 & 1 & 1 & 1 \\
\hline $\begin{array}{l}\text { Are confidence intervals given for } \\
\text { the main outcome? }\end{array}$ & 1 & 1 & 1 & 1 & 1 & 1 & 1 & 1 & 1 \\
\hline $\begin{array}{l}\text { Are there any confounding factors } \\
\text { that haven't been taken into } \\
\text { account? }\end{array}$ & $\mathrm{O}$ & O & O & $\mathrm{O}$ & $\mathrm{O}$ & O & O & O & O \\
\hline $\begin{array}{l}\text { Are the results applicable to your } \\
\text { research? }\end{array}$ & 1 & 1 & 1 & 1 & 1 & 1 & 1 & 1 & 1 \\
\hline Total & 9 & 9 & 10 & 9 & 9 & 10 & 9 & 9 & 9 \\
\hline
\end{tabular}

Note: $\mathrm{Yes}=1, \mathrm{No}=0$ 
Tabel 4. Critical Appraisal Checklist for Cross sectional Study

\section{Checklist questions}

Does this objective address the

focus/research problem?

Is the research method (research design)

appropriate for answering research

questions?

Is the method of selecting research

subjects written?

Can the sampling method raise bias

(selection)?

Does the research sample taken represent

the designated population?

Is the sample size based on pre-study

considerations?

Is a satisfactory response achieved?

Are the research instruments valid and

reliable?

Is statistical significance assessed?

Are confidence intervals given for the main outcome?

Are there any confounding factors that

haven't been taken into account?

Are the results applicable to your

research?

Total

Note: $\mathrm{Yes}=1, \mathrm{No}=\mathrm{O}$

Mogre et Zou et Roman

al. al. et al.

(2015)

(2017)

(2019)

1

1

1

1

1

1

1

o

1

1

1

1

1

1

1

o

0

1

10

$1 \quad 1$

o

1

1

1

1

1

o

1

$\begin{array}{cc}\text { Okube } & \text { Shrestha } \\ \text { et al. } & \text { et al. }\end{array}$

et al.
$(\mathbf{2 0 2 0})$

1

(2015)

1

1

1

1

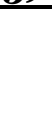

1

o

1

1

1

O

1

1
1

1

1
1

\begin{tabular}{|c|c|c|c|}
\hline $\begin{array}{c}\text { O'Brien }^{\prime} \\
\text { et al. } \\
(2020)\end{array}$ & $\begin{array}{c}\text { Lee et } \\
\text { al. } \\
(\mathbf{2 0 1 8})\end{array}$ & $\begin{array}{c}\text { Yin et } \\
\text { al. } \\
(2020)\end{array}$ & $\begin{array}{c}\text { Dagne } \\
\text { et al. } \\
\text { (2019) }\end{array}$ \\
\hline
\end{tabular}

1

1

1

1

1

1

\begin{tabular}{|c|c|c|c|}
\hline 1 & 1 & 1 & 1 \\
\hline 1 & 1 & 1 & 1 \\
\hline 1 & O & $\mathrm{O}$ & O \\
\hline 1 & 1 & 1 & 1 \\
\hline $\mathrm{O}$ & O & $\mathrm{O}$ & 1 \\
\hline 1 & 1 & 1 & 1 \\
\hline 1 & 1 & 1 & 1 \\
\hline 1 & 1 & 1 & 1 \\
\hline 1 & 1 & 1 & 1 \\
\hline $\mathrm{O}$ & $\mathrm{O}$ & $\mathrm{O}$ & $\mathrm{O}$ \\
\hline 1 & 1 & 1 & 1 \\
\hline 10 & 9 & 9 & 10 \\
\hline
\end{tabular}




\section{DISCUSSION}

Research studies and systematic metaanalysis use of research to control confounding factors that can be seen from inclusion research are the multivariate analysis and statistical results reported were adjusted odds ratio (AOR).

Estimates of combined diet as a risk factor for Diabetes Mellitus was in the RevMan 5.3 application. The systematic study results and meta-analysis are presented in the form of a forest plot and a funnel plot. Forest plots provide an overview of each of the studies examined in the meta-analysis and estimates of the overall results (Murti, 2018).

The funnel plot shows the amount of variation (heterogeneity) (Akobeng, 2005 in Murti, 2018) visually. The funnel plot shows the relationship between the study's effect size and the sample size of the various studies studied, which can be measured in several different ways (Murti, 2018).

Dietary Pattern as a Risk Factor for Diabetes.

The forest plot results showed that an unhealthy diet increased the risk of obesity by 1.42 times compared to a healthy diet $(\mathrm{aOR}=1.42 ; 95 \% \mathrm{CI}=1.21$ to $1.66 ; \mathrm{p}$ <0.001). This is according to the theory that food plays a role in increasing blood sugar levels. In eating, the food eaten will be digested in the digestive tract and then converted into a form of sugar called glucose (Sum Transport, 2013).

Zaroudi (2016) stated that if you often consume unhealthy foods such as high consumption of salt, offal, sweet dried fruits, animals, and tea, they can increase the risk of developing diabetes mellitus by 2.17 times compared to those who do not consume these foods $(\mathrm{aOR}=2.17 ; 95 \% \mathrm{CI}=1.0$ to $4.50 ; p=0.024)$. The result of rapid changes in lifestyle, physical activity, diet, and better socioeconomic status in Iran has led to an unhealthy diet similar to the western pattern. An unhealthy diet is one of the risk factors for diabetes, the diet that is meant here is an unhealthy diet such as high fat, high carbohydrate, high sugar, aka sweet drinks, drinking alcohol that is done almost every day (Beigrezaei, 2019). Diets that develop with more protein and meat consumption also cause a decline in glucose metabolism (Nguyen, 2016).

\section{Dietary Pattern as a risk factor for obesity.}

The results of the forest plot research article that was processed with Revman 5.3 showed that an unhealthy diet increased the risk of obesity by 1.42 times compared to consuming healthy foods $(\mathrm{aOR}=1.42$; 95\% $\mathrm{CI}=1.21$ to 1.66 ; $\mathrm{p}<0.001)$. This research is in line with the theory that dietary pattern is a risk factor for obesity.

This study is supported by a study conducted by Ali (2018), which stated that consumption of unhealthy foods such as fast food (high fat and high carbohydrates) $\geq 3$ times per week increases the risk of obesity 1.82 times compared to $<3$ times a week. The statistical results obtained $\mathrm{aOR}=$ 1.829 (95\% CI; 1.33 to 2.50 ).

According to Azkia (2018), consuming fried and high-fat foods increases the risk of obesity by 1.03 times compared to those who do not eat the food $(\mathrm{aOR}=1.03 ; 95 \%$ $\mathrm{CI}=0.9$ to $1.1 ; \mathrm{p}<0.001)$. This is also in accordance with a study conducted by Guallar \& Castillon, which showed that fried food was positively related to central obesity because it can produce high energy intake. Consumption of fatty foods can increase stomach circumference and body weight. Besides, the consumption of fatty foods is a factor associated with obesity.

Chamieh (2015) stated that an unhealthy diet such as consuming lots of highcarbohydrate foods (rice, bread, processed flour) and high-fat fast food would increase 
the risk of obesity by 2.03 times in adults compared to those who do not consume these foods. $(\mathrm{aOR}=2.0 ; 95 \% \mathrm{CI}=1.24$ to $3.34 ; \mathrm{p}<0.001)$.

This meta-analysis concluded that an unhealthy diet high in fat, high in sugar, high in carbohydrates increased the risk of developing diabetes $(\mathrm{aOR}=1.65 ; 95 \% \mathrm{CI}=$ 1.29 to 2.11 ; $\mathrm{p}<0.001$ ). This meta-analysis combines 9 primary studies using a crosssectional design from Swaziland, China, Ethiopia, Kenya, the United States, and Malaysia.

This meta-analysis concluded that an unhealthy diet containing foods high in fat, high in carbohydrates, fried foods, junk food and drinking lots of soda increased the risk of obesity in adults $(\mathrm{aOR}=1.42 ; 95 \%$ $\mathrm{CI}=1.21$ to $2.66 ; \mathrm{p}<0.001$ ). This metaanalysis combines 9 primary studies using a cross-sectional design from Ghana, China, Romania, Kenya, Nepal, Ireland, Korea, and Ethiopia.

\section{AUTHOR CONTRIBUTION}

Linda Wahyu Septianawati was the main researcher who selected the topic, explored, and collected research data. Yulia Lanti Retno Dwi and Eti Poncorini Pamungkasari played a role in analyzing data and conducting research document reviews.

\section{CONFLICT OF INTEREST}

There is no conflict of interest.

\section{FUNDING AND SPONSORSHIP}

This study used private funds from the principal investigator.

\section{ACKNOWLEDGEMENT}

The authorswould like to express their gratitude to the database providers PubMed, Google Scholar, and Springer Link.

\section{REFERENCE}

Ali R, Nuryani (2018). Sosial ekonomi konsumsi fast food dan riwayat obesitas sebagai faktor risiko obesitas. Media Gizi Indonesia. 13(2). DOI: 10.20473/mgi.v13i2.123-132.

Azkia FI, Wahyono TY (2018). Hubungan pola konsumsi makanan berisiko dengan obesitas sentral pada wanita usia 25-65 tahun di Bogor Tahun 2011-2012. Jurnal Epidemiologi Kesehatan Indonesia. 2(1).

Beigrezaeisara, Ghiasvand R, Awat F, Bijan I (2019). Relationship between dietary patterns and incidence of type 2 diabetes. Int J Prev Med. 10: 122. https://dx.doi.org/10.4103\%2Fijpvm. IJPVM_206_17.

Chamieh MC, Moore HJ, Summerbell C (2015). Diet, physical activity and socioeconomic disparities of obesity in Lebanese adults. BMC Public Health. 15, 279 (2015). https://doi.org/10.1186/s12889-015-1605-9.

International Diabetes Federation (IDF) (2017). Diabetes atlas seventh edition 2017. Dunia: IDF.

Kadir A (2016). Kebiasaan makan dan gangguan pola makan serta pengaruhnya terhadap status gizi remaja. Jurnal Publikasi Pendidikan. 5(1).

Nabilah (2016). Faktor risiko perilaku penyakit tidak menular. Med J. 5(2). https://juke.kedokteran.unila.ac.id/in dex.php/majority/article/view/1082

Nguyen CT, Pham NM, Tran DV, Lee AH Binns CW (2016). Lifestyle and diet in relation to risk of type 2 diabetes in Vietnam. SpringerPlus. 5(1): 687. https://doi.org/10.1186/s40064-0162313-3.

Singh M, Czernichow S, Elbaz A, Dugravot A, Sabia S, Hagger G, Kivimaki M (2012). Obesity phenotypes in midlife and cognition in early old age: The 
Septianawati et al./ Dietary Pattern As a Risk Factor of Diabetes Mellitus and Obesity

Whitehall II cohort study. J Neurol. 79(8):755-62 Doi: 10.1212/wnl.obo13e3182661f63.

Sumangkut S, Supit W, Onibala F (2013). Hubungan pola makan dengan kejadian penyakit diabetes melitus tipe-2 di RSUP. Prof. Dr. R. D. Kandou Manado. Ejournal keperawatan (eKp). 1(1).
WHO (2018). Mental Health. Geneva: World Health Organization.

Zaroudi M, Jamshid Y, Sharmin M, Elham G, Jalal N, Hamid S, Bahar N, et al. (2016). Dietary patterns are associated with risk of diabetes type 2. Arch Iran Med. 19 (3): 166-72. PMID: 26923887. 